\title{
'As It Was in the Beginning': An Examination of the Convergence, Divergence and Dilemmas of Immigration Practices in Some Selected Liberal Democratic States
}

\author{
Cosmas Ikegwuruka ${ }^{1}$, Ugonna Chimnonyerem Nkwunonwo ${ }^{2}$ \\ ${ }^{1}$ Almond Legals-immigration, Asylum and Human Rights Lawyers \& Researchers, London, UK \\ ${ }^{2}$ Department of Geoinformatics and Surveying, University of Nigeria Enugu Campus, Enugu, Nigeria
}

Email address:

almondlegals@yahoo.co.uk (C. Ikegwuruka), ugonna.nkwunonwo@unn.edu.ng (U. C. Nkwunonwo)

\section{To cite this article:}

Cosmas Ikegwuruka, Ugonna Chimnonyerem Nkwunonwo. 'As It Was in the Beginning': An Examination of the Convergence, Divergence and Dilemmas of Immigration Practices in Some Selected Liberal Democratic States. International Journal of Law and Society. Special Issue: Immigration Control, Citizenship, the Interplay of Sovereignty and the Vicissitudes of the Hostile Environment.

Vol. 3, No. 2, 2020, pp. 68-77. doi: 10.11648/j.ijls.20200302.14

Received: February 13, 2020; Accepted: March 11, 2020; Published: May 28, 2020

\begin{abstract}
This paper holds the view that the burgeoning phenomenon of immigration control sits uncomfortably on the fault line separating the prerogatives of State sovereignty from the rights of non-citizens regardless of the broad discretion of States to control immigration. Using liberal democratic ideologies, the paper expresses that, there is in existence, a tension between the right to liberty of migrants against the broadly unfettered rights of States to control the admission and expulsion of migrants conferred on States by national and international law. Drawing from law and policy, this paper considers in perspectives, immigration practices in selected liberal democratic states-the United States of America, Australia and France whose deportation reality offers significant similarities with the UK in immigration control and detention pending expulsion. Finding as it did, the paper illustrates that crimmigration in particular and immigration enforcement and control in general, serve as vehicles for enhancing and sustaining expulsion of migrants. This practice, it is argued, queries the liberal democratic ideals of fairness in particular and compliance to international human rights standards in general.
\end{abstract}

Keywords: Expulsion, Crimmigration, Detention, Liberal Democracy and Sovereignty

\section{Introduction}

As it has been expressed by Flynn [1], 'the burgeoning phenomenon of immigration control sits uncomfortably on the fault line separating the prerogatives of State sovereignty from the rights of non-citizens regardless of the broad discretion of States to control immigration'. It will be argued that, there is in existence, a tension between the right to liberty of migrants against the broadly unfettered rights of States to control the admission and expulsion of migrants conferred on States by national and international law [2]. When it comes to liberal democracies, this paper argues that tension exists in establishing boundaries between individual and collective rights as it concerns international human rights law relating to detention and expulsion (removal and/or deportation) of migrants on the one hand and the protection of the rights of others on the other hand. This tension (between the right of individuals and the protection of the rights of others such as the protection of society as a whole), places the liberal state in a difficult position when making decisions affecting the rights of non- nationals, which may be deemed incompatible with acceptable standards under international human rights law in the context of the exercise of sovereignty resulting from immigration control. Gibney and Hansen [3] have argued that the restrictiveness of the liberal State's policy towards non-nationals attempting to secure their immigration status in the State 'can be seen as flowing from the liberalism (intentional or otherwise) of its policy towards foreigners inside the state. Inclusion and exclusion are two sides of the same liberal coin' (emphasis added). In this connection, I will seek to unravel the legitimacy of immigration practices and the extent of its unlawfulness, if at all, thereby querying the availability of the rights of migrants in the face of expulsion and any attendant 
obstacles militating against the exercise of these rights in the host State.

For a regime to be considered a liberal democracy, it must be democratic in the sense that it must protect the rights of individuals and minorities thus guaranteeing freedom or liberty of its citizens and others, with the guarantees expressly stated in its constitutional framework with the government, further limited by the rule of law [4]. Therefore, liberal democratic ideologies and/or constitutions define the democratic character of States where the constitution serves as a limit on the authority of the government that delineates separation of powers, judicial independence and checks and balances between governmental organs thus emphasizing the importance of the rule of law [5]. A liberal democracy sees itself as inseparable from international human rights with the aim of applying the rights effectively and properly matched with individual and collective responsibilities [6].

Drawing from anecdotal evidence, law and policy, this paper considers in perspectives, immigration practices in selected liberal democratic states-the United States of America, Australia and France whose deportation reality offers significant similarities with the UK in immigration control, detention pending expulsion. This is in order to put the analysis of expulsion issues in the UK within the broader context of other liberal democracies by way of convergence, divergence, diffusion and dilemmas of practices in immigration control. The reason for the above selection is that the UK, USA, Australia and France are major receiving countries in terms of immigration. They are equally liberal democratic countries given their constitution and democratic practices. While USA and Australia are outside the European Union, the UK and France are within the European Union. It has been argued that Europe over time has become the western target of immigrant flows. As a result, migration policies seem to have increased rapidly with the reaction that they have adopted expulsion and detention as standard practices [7].

\subsection{Immigration Realities and Similarities, the United Kingdom and Other Liberal States-Convergence, Divergence and Trends}

The idea behind this exploration is to assess whether the dilemmas faced by these countries are inherent in liberal democratic states as standard practices with the further aim of exploring the convergence, divergence and diffusion of practices or whether they are mere coincidence.

The Aliens 1905 Act in the UK, as has been recorded, permitted Immigration Service inspectors not only to detect and refuse aliens entry into the UK but also to deport [8]. The Aliens Act 1905 was the first major piece of modern immigration legislation that marked the inception of the Immigration Act and the appeal system [9]. At about this time, there appears to be a convergence of practice in immigration control with respect to other liberal democratic States such as Australia and the US. So, in 1901, the Commonwealth Parliament of Australia enacted the Immigration Restriction Act 1901 with respect to immigration and emigration prohibiting the immigration into the Commonwealth of any person who failed a certain dictation test in a European language [10]. This Act therefore was one of the first legislative measures that did not allow non-whites to enter the country except on a temporary basis under permit having already passed the Chinese Immigrants Regulation and Restriction Act 1861 [11]. The Act also provided for the exclusion of other classes of immigrants such as criminals, later to be found in the Migration Act 1958 [12]. This as this research shows, is similar to the UK's immigration practice [8].

Drawing from the United States' position, certain categories of people were also excluded in 1907 such as people with physical or mental defects or tuberculosis and children unaccompanied by parents and in addition, Japanese immigration became restricted [13]. This exclusion list was further expanded in 1917 with the addition of illiterates, persons of psychopathic inferiority, men as well as women entering for immoral purposes- alcoholics, stowaways, and vagrants [13].

The UK's 1971 Immigration Act on the other hand became the cornerstone of all immigration laws in the UK with the interplay and introduction of partiality, discretions, unpublished guidelines, rules and policies [8]. As it will be seen, about the period between 1971-1999 similar immigration revolutions were in operation in the US and France that relieves the argument whether such practices were simply co-incidental, a trend amongst liberal democratic states or mere convergence. It raises fundamental questions whether the style, form and pattern of immigration control in liberal democratic states expose as it did, the emergence of a new legal framework of state power.

In the USA, in 1952, the multiple laws, which governed immigration and naturalization to that time, were brought into one comprehensive statute called the Immigration and Nationality Act (INA) [14]. Then came the Immigration Reform and Control Act 1986 (IRCA) that was a comprehensive reform effort which amongst other things was created to legalize aliens who had resided in the United States in an unlawful status since January 1, 1982. The Legal Immigration and the Immigration Act of 1990 that provides for caps on immigration (similar to the UK's immigration cap policy) further provided for all grounds for exclusion and deportation, significantly rewriting the political and ideological grounds and repealing some grounds for exclusion [15]. The highpoint of all reforms in the USA was the Illegal Immigration Reform and Immigrant Responsibility Act (IIRAIRA), enacted in 1996. This Act was and as it is presently aimed to have a lasting effect on immigration control with provisions aimed at adopting stronger penalties against illegal immigration, streamlining expulsion practice by curtailing the appeal process. The main provisions of the Act include inter alia the barring of legal admission for removed illegal aliens and permanently barred admission for deported or removed aggravated felons [16], the creation and the facilitation of deportation of criminal aliens by expanding the definition of aggravated felony to 
include crimes carrying a prison sentence of one year or more rather than time served [17].

In France, the governments from the mid-1970s and $1980 \mathrm{~s}$ tried to stop immigration through different measures. An internal control was instituted through "inspecteurs dutravail" that made unexpected work checks and had the power to sanction employers if any illegal employee was found [18]. Charles Pasqua, as minister of the interior in the Chirac government, dealt with the problem through the border police - he increased the power of the "Police de l"Air et des Frontieres" to undertake border controls, to detain and deport [19]. In the early 1980s, immigration became a major political issue with the rise of the National Front and growing challenges from North Africa [20]. In effect, the early 1990's saw France pursue a zero-immigration policy where numerous regulations were tightened through the Pasqua Laws, which amongst other measures expanded the powers of immigration authorities to deport non-citizens leading to protests, by Africans and Chinese called the campaigns of the 'san papiers' [21].

Therefore, the trend amongst all the liberal democratic states is that they all appear to have adopted a harder stance against migrants' admission and settlement between the years 1958-1990 and even to date. While the UK used 'not conducive to public good' term as a ground for deportation, the USA facilitated the deportation of criminal aliens by expanding the definition of aggravated felony to include crimes carrying a prison sentence of one year or more rather than time served. France as we saw used the Pasqua laws to expand the deportation regime through the grant of special powers to immigration officers to detain and deport aliens [22]. In France, Schuster [23] had specifically reported that there are those (Afghanistan nationals or residents) whose 'asylum applications had been refused by the French government, so are 'rejected asylum seekers' but as France finds it difficult to deport to Afghanistan, they are stuck in France without status as illegal migrants', these remain in a legal limbo with no chance of regularizing their stay in the country.

\subsection{The Coincidence and Diffusion in the Exercise of Discretion}

The UK is not alone in the typical use of discretion in immigration control. By way of drawing from Australia's practice, another liberal democratic state, evidence shows a convergence in the use of discretion. The Australian Migration Act of 1958 and the Migration Amendment Act of 1983 are relevant here. The Migration Act 1958 is described by its preamble as 'An Act relating to the entry into, and presence in, Australia of aliens, and the departure or deportation from Australia of aliens and certain other persons' [24]. The Migration Act, 1958 contains a wide range of discretionary powers incumbent on the minister, "in his absolute discretion" including delegation of powers to authorized persons [25]. These discretionary powers are related to arrangement for entries and deportations. In the words of Ozdowski [24], 'The Migration Act 1958 contains a level of discretion unknown even in other "machinery" legislation conferring a wide range of discretionary power on the minister or those authorized by him'. Viewed from the perspective of the UK Immigration system, Regulations are also made to implement the Act as can be seen from the perspective of the Migration Act 1958, which makes the Regulations addressing issues of procedures [26]. The Department of Immigration and Ethnic Affairs (DIEA) makes administrative and procedural rules, which are not usually subject to public announcement, but are communicated through the issuance of instructions and through periodical up-dates to the departmental manuals [24].

Arguing systematically from a normative standard as gathered from the various States' practices is the contention 'that there is an underlying tension between liberal values including the belief in the universality of human rights and democratic values which surfaces in form of an irresolvable dilemma when liberal democratic States are confronted with the issue of how they should treat migrants' [27]. Immigration control on its part has a strong reliance on spectacle where the migration regime must be perceived as competent and for the State to act powerfully in the defense of its borders [28]. Therefore, the control of immigration is generally seen, as one of the central prerogatives of national sovereignty but international human rights obligations require States to comply with their treaty obligations regarding the treatment of aliens in their territory rather than mere exercise of discretion [29].

However, given the strong presence of the European Union Law, it is commonplace and now a requirement of EU Law that the rights guaranteed under the European Convention of Human Rights (ECHR) are respected as general principles of EU law [30]. This is why Finch argues that it is 'plausible to construct an approach to immigration in the UK within the remit of liberal democracy with broad appeal which is neither open door nor fortress UK to manage and limit migration in the national interest while at the same time being a welcoming place for migrants and to build a new patriotism which embraces and encompasses diversity' [31]. Therefore, this research shares the argument that 'immigration law serves as instruments to supply and refine parameters of both discipline and coercion largely through laws as tactics, which cannot totally guarantee certainly of their realization' [32]. It can therefore be surmised that the convergence, divergence and trends in immigration control in the mentioned liberal democratic states appear not to exist by sheer co-incidence but an indication of some sort of policy transfer, diffusion or even legal transplant as exemplified by their respective State practices viewed in perspectives which may have implications for their international treaty obligations.

\section{Detention and Liberal Democracies: Trends and Turns}

The detention of migrants in the UK was first undertaken 
under the 1920 Aliens Act, which gave enormous powers to immigration officers to deport aliens. This was further elaborated under the 1971 Immigration Act (1971 Act) as provided under Schedule $2 \& 3$ to the 1971 Act [33]. This power, as observed by Johnston, can be exercised in conjunction with any of the three administrative acts notably examination, removal or deportation [34]. In the view of Block and Schuster, 'the powers to detain are very wide and not subject to any automatic scrutiny of the lawfulness, appropriateness or length of detention' [35]. The 1971 Act authorized detention in several situations concerning examination, decision to grant leave and administrative removal [36]. In Khan $v$ SSHD [37] the court confirmed that the prohibition on removal pending the pursuit of an asylum claim does not preclude the exercise of the power of detention [38].

In offering significant similarities with the UK, the United States on its part in 1892, even prior to the advent of the UK laws and policies on detention, authorized mandatory immigration detention for all non-citizens seeking entry into its territory that led to the establishment of Ellis Island as the first immigration detention centre and the most frequently used, popularly referred to as the "Island of Tears" [39]. Furthermore, the Immigration and Nationality Act (INA) 1952 gave special permission to the Attorney General to detain non-citizens for ninety days under the post removal detention statute-mandatory immigration detention [40].

By way of diffusion and trends, immigration detention in the UK and the US has become restrictive over a given period of time. In characterizing the US immigration, Silverman opined that 'detention has become more restrictive with time, with periods growing larger and conditions becoming deleterious with less accountability' [41]. Of critical consequence here is the retroactivity clause entrenched in the Immigration Reform and Immigration Responsibility Act 1996 (IIRIRA) that streamlined removal proceedings through its Immigration and Custom Enforcement (ICE) of which immigration detention was the centerpiece and non-citizens as targets. This paper argues that the retroactivity clause of the US 1996 Act closely resembles section 32 of the UK Borders Act 2007, which has a retroactive effect against foreign nationals who may have committed offence before the law came into force. The massive expansive of immigration detention in the USA, which Miller contended was a result of the retroactivity of the 1996 legislation mandatory detention provisions in addition to the expandable categories of deportable offences [42], as the Section 32 of the UK Borders 2009 made criminal conviction as a basis for deportation. As Loughran saw it, the 'pre-September 112001 legislation in the US marked a paradigm shift in immigration policy from individual -based focus to a categorical approach fed by the popular perception that migrants arriving the US are a faceless crowd that must be detained' just like the approach adopted in the UK [43].

\subsection{The Administration of the Detention Regime}

Detention regime in the UK and the US is at the nexus of foreign and domestic policies, instrumentalized at various times in response to both'. Commenting on the US detention, Miller [42] and another [44] had stated that immigration detention provides a unique variation as it showcases the manipulation of administrative policy in deterring potential future migrants [45]. In Australia and by way of convergence, the power to detain migrants is enshrined in the Australian Migration Act 1958 and tested under common law in the case of Al Kateb v Goodwin [46]. The Australian Migration Act 1958 provides for administrative detention of non-nationals and that detention is mandatory not discretionary [47]. Section 189 authorizes an officer to detain a person whose presence he suspects or reasonably believes to be unlawful. Section 196 (1) deals with the period of detention, which provides that detainees under section 198 must be detained until removed, deported, or granted a visa. Section 196 (3) prevents a person being detained from release even by a court of an unlawful non-citizen. In $\mathrm{Al}$ Kateb $v$ Godwin [46], the Australian High Court (highest court in Australia under the hierarchy of courts) decided by a narrowest 4-3 majority rejecting the appellant's argument that he should be released from detention. The court stated the Migration Act 1958 interpreted clearly provides that he will be kept in administrative detention until he is removed, meaning that the appellant is to be kept in administrative detention indefinitely if not removed. In his contribution to the Australian detention debate, Allan argues that the ability to detain flows from the purpose of detention which is removal and where that purpose no longer has any real likelihood of fulfillment, detention stops being lawful [48]. To him, that allows one to avoid the otherwise seemingly clear words of s 196 (3) [49]. It is important to point out that the UK, US and Australia use similar phrases of 'reasonably necessary', 'reasonably foreseeable' or 'reasonably practicable' respectively to defend their practice of indefinite immigration detention against international human law standards - a dilemma faced by migrants in these liberal democracies.

Furthermore, it is argued that the power of the courts in Australia to specifically review the legality of such detention has been removed by operation of law [50]. This lack of effective means of appeal or review has invited the UN Human Rights Committee to hold that such detention is 'arbitrary' within the meaning of Article 9 of the ICCPR [51]. In addition, the High Court of Australia in late 2003 surprised human rights advocates and the international community by entering a unanimous decision, where it considered it not to be unlawful or unconstitutional to detain children in immigration detention, stating that there were no exceptions to the law for children [52]. Similarly, another High Court case added a salvo to the matter by finding that conditions of detention would not make an otherwise lawful detention, unlawful [53]. This decision appears to be at variance with the Human Rights Committee's views in which 
it held that article 9 (4) of the ICCPR requires that detained individuals be entitled to review by a court and that any review must be effective, most notably, that a court must be able to order release [54].

France on the hand tilts towards a contrast to immigration detention as practiced in Australia, USA and the UK. It has been reported that as at 31 March 2004, migrants notably asylum seekers are generally not detained in France while decisions on their claims for asylum are pending [54: Fields $\&$ Edwards]. It is recorded that the maximum time permitted in a waiting zone is 20 days [54], and in the event of impossibility of detention, admission must be allowed with a functional appeal system that allows for a référéliberté to the Tribunal, which is decided upon very quickly-within a few days [55]. As at 2003, there were 24 centres (with 775 beds) registered as places of rétention in addition to over one hundred other places, which can be temporarily used as sites of retention, such as, police stations or, exceptionally, hotel rooms [54]. In 2003 and to date, the percentage of asylum seekers released from waiting zones and admitted to French territory was $68.8 \%$. [54] Viewed in perspectives with state practices in the UK, USA and Australia, it appears that French detention policies and practice tilt more towards conformity to international human rights standards.

But legal developments in the detention estate are worrisome and challenging. In Saadi $v U K$, the ECtHR concluded that 'until a State has authorized entry to the country any entry is unauthorized and the detention of a person who wishes to effect entry and who needs but does not have authorization to do so can be, without any distortion of language to 'prevent his effecting an unauthorized entry'. Even though it is accepted that the Convention is a 'living instrument' [56] which accepts proactive and teleological approaches but the Strasbourg court in Saadi seems to have used it in expanding the limitations on the fundamental right to liberty. As O'Nions argues, 'the consequence of that interpretation is that any person without express leave to enter or remain in the UK could now be detained as their presence is similarly unauthorized under Art 5 (1) (f) [ECHR]'. However, later developments [57] tilt towards a contradiction of the necessity nexus in immigration detention rejected by the ECtHR in Saadi $v$ UK. The ECtHR in Rusu v Austria [58] (a case postdating Saadi) surprisingly abandoned its previous stance and accepted that the necessity adjunct was very vital in the applicable domestic law but nevertheless refused to incorporate it into its interpretation of Art 5 (1) (f) on detention. Costello [59] sees this 'as signaling a more intense judicial review of both adherence to domestic standards and the factual matrix surrounding the claim of unauthorized entry'. She remarked that by 'rejecting the necessity test in the deportation-detention nexus, the Court explicitly sets a lower standard of protection for immigration detention than for other forms' [59].

By way of divergence and trend, the US Supreme Court in Denmore v Kim [60] similar to Saadi v UK, had to decide the issue of necessity in immigration detention. Denmore was the second Supreme Court case decided in 2003. The court although divided, accepted that government's rationale for mandatory detention was a means to compensate for its own inefficiency and lack of resources but went ahead to reject information suggesting that necessity is required in immigration detention in all cases of criminal non-citizens [61]. Therefore the issue of necessity in immigration detention as was decided in Saadi [56] by the ECtHR in 2008, where the State does not have to show that detention was necessary only if removal of the migrant was pursued with due diligence, somehow suggests that the ECtHR borrowed extensively from Denmore by way of diffusion.

\subsection{Detention and the Use of Private Companies}

The use of private companies in the immigration detention estate reflects the norm in most liberal democracies such as the USA, UK and Australia, which led Beyen and Snacken to remark that 'What happens in the USA today happens in the UK tomorrow' [62]. This could be interpreted to mean that liberal democracies appear more interested in encouraging detention than the respect of the right to liberty of noncitizens. Tim Newburn adds that the emergence of private prisons and detention centres in the UK owes its motivating developments to the USA in what is referred to as 'policy transfer' [63]. Garland [64] describes it as shared culture of control, assisting to shape penal policies with increasing similar outlook. Writing from a symbiotic, cross-pollinated and axiomatic viewpoint, Jones and Newburn see it as 'elements of globalisation emerging from policy ideas implemented across international boundaries when political conditions are ripe' [65]. In the opinion of James, the growth of immigration detention, may not be based solely on restrictive asylum and immigration policies but can be attributed to the involvement of private companies whose concern is to win and maintain contracts and to keep their facilities full [66] even as immigration detention has been identified as a highly profitable venture for the growing incarceration business in recent years as bidding is done for prisons and immigration detention centres as well [67].

\section{Crimmigration as a Springboard to Expulsion}

Crimmigration was developed by the American Migration jurisprudence to connote the 'convergence of two critical regulatory regimes-criminal justice and immigration control where the two systems intersect at multiple points notably at points that violations of the immigration laws trigger broader, harsher, and more frequent criminal consequences even leading to migrants and/or refugees being prosecuted for illegal [irregular] entry' [68]. 'Crimmigration narrows the decision whether to exclude the migrant out of the State to a single moment in time-the moment of crime, compelling enough, to trigger the potential for deportation or detention for an immigration offense' [69].

The UK Borders Act 2007 ("2007 Act") amplified the issue of crimmigration with its mandatory deportation under 
section 32 with exceptions under section 33 [70]. Consequentially, a direct link between deportation and the commission of a crime of the appropriate level of severity has been created which ultimately reduces the scope for challenging automatic deportation decisions through the appeals system [71]. The obvious implication is that Parliament lengthened the list of immigration related offences from the 1971 Act to a major 'catch all' law by the instrumentality of the 2007 Act which rather than rely on immigration related offences alone but now relies on all offences carrying a sentence of more than 12 months. The reasoning is that any migrant convicted of any offence at all, is liable to deportation either under the 'not conducive to public good grounds' or by way of automatic deportation under the 2007 Act. By so doing, crimmigration justifiably implores the conduct of the migrant and the length of imprisonment to expand deportation categories.

The section 33 exceptions of the 2007 Act as a counterpoise to deportation has not alleviated the potency of section 32 in automatic deportation cases thereby illustrating the effect of crimmigration as a contrivance of deportability [72]. It is typical of courts to find following a conviction that deportation was conducive to public good, even where families with children were involved, 'the best interest of the child' [73] did not save their parent (s) from being deported [74]. As the court stated in Rocky Gurung $v$ SSHD, "the Borders Act by s. 32 decides that the nature and seriousness of the offence, as measured by the sentence, do by themselves justify deportation unless an exception recognized by the Act itself applies" [74]. Therefore, without the application of a criminal conviction, deportation may not have been justified under this limb.

Similarly, in the United States, the crimmigration debacle has assume exponential dimensions in the light of evidence that over the past two decades, the U.S. Congress has through the accumulation of legislative Acts, steadily expanded the scope of criminal conduct which underlies deportation [75]. As Stumpf identifies, deportation based on the commission of aggravated felony has expanded from the original three grounds notably murder, drug trafficking and firearms trafficking to what she refers to as 'an alphabet of crimes of lesser gravity' [69]. Therefore, [76] through the instrumentality of legislation, immigration related conducted have been termed criminal with harsher sanctions for the violation of immigration law imposing incarceration as a ground for deportation [77]. The USA's Illegal Immigration Reform and Responsibility Act 1996 ("IIRIRA") [78], allows retroactive punishment, by way of convergence to the UK Borders 2007 Act which in its Explanatory Note permits deportation of those already convicted prior to the coming into force of the law [79].

Unlike IIRIRA and the Anti-Terrorism and Effective Death Penalty Act 1996 ("AEDPA") which allow cancellation of deportation under the defense of 'exceptional and extremely unusual hardship' for the migrant's family, the UK's 2007 Act created exception to automatic deportation under its section 33 on grounds of breach of human rights or age of the offender [80]. But contrary to IIRIRA and AEDPA which specified all offences-aggravated felonies attracting deportation [81], the UK's 2007 Act by way of divergence excludes all offences less than 12 months but such offences remain deportable offences under the "not conducive to public good" limb enshrined in the 1971 Immigration Act [82]. The IIRIRA through its section 287 (g) generally referred to as '287 (g) agreements' made provision authorizing state and local police to identify and turn over to the Immigration and Customs Enforcement ("ICE") any suspected criminal immigrant encountered during regular enforcement activities, [83] with convergent enforcement patterns in the UK [84]. These deportation enforcement practices in the UK and the U.S. are similar in style and approach to the extent that it could be termed a legal transplant or policy transfer [85].

Crimmigration, it is argued, exposes a malaise, which in adjudicative proceedings pays little or no attention to discretion not to deport [86], with judges and officials lacking the authority to stay deportation in the face of separation of families that may lead to destruction of such families [87]. In short, the relationship between criminal law and immigration law has become so inextricably intertwined to the extent they switch roles implying that the decision to deport are indirectly made through criminal justice institution at the point of conviction while the actors, functions and institutions in the criminal justice system have shifted allowing immigration objectives to dictate criminal prosecution [88]. The point being made by these divergent and convergent practices as exemplified by some sort of policy transfer is that they accomplish enforcement goals accompanied through lack of attention to the rights of migrants [89], which this paper argues, is the behaviour and character of liberal democracies. As Markowitz posited, 'migrants have no right to protection against retroactive changes in law and they can be deported for minor criminal and other offences at the pleasing of the State' [90].

In Australia, the main legislation for the deportation of migrants is the 1958 Migration Act with its later amendments [91]. Section 12 of the Act contains broad discretionary powers exercised by the Minister to deport an alien [migrant] convicted of a particular crime or sentenced to imprisonment of one year or more. This provision is in identical terms with the UK Borders Act 2007- the identical decimal being criminal conviction, a product of 'character test' as in Australia [92]. It is crucial therefore to note that while section 32 of the UK Borders Act 2007 makes provision for automatic deportation of 'foreign criminals' as discussed above, the Australian section 501 of the Migration Act on the other hand is used to deport those under the 'character test' regardless of their length of residence. It is therefore contended that this supposedly synergy of deportation practices in the form of convergence could not have been an accident. Using criminality as a springboard for deportation could better be explained as the exportation of the State's problem elsewhere with no reasonable consideration of their human rights.

In France, the deportation of migrants gained fervor with the 
2003 legal reform centres de retention, which extended the maximum time of detention of migrants to 32 days thus providing an amphitheatre for large-scale deportation [93]. This was followed by the imposition of deportation quotas on prefets-law enforcement officers from several departments forcing them to increase the number of irregular migrants, charged with deportation and actually removed from the country [93]. Nonetheless, the French Immigration law prohibits expulsion in these limited circumstances [94], and it appears that France has not made criminal conduct a major policy plank in the deportation of migrants by way of divergence but has made the use of quotas and targets as a convergent practice similar to the UK. This therefore illustrates that the deportation realities of the United States, Australia and France within the broader context of liberal democracies offer significant similarities with the UK, with specificity to crimmigration in particular and immigration enforcement and control in general. And this serves as a vehicle for enhancing and sustaining deportation of migrants which queries the liberal democratic ideals of fairness in particular and compliance to international human rights standards in general.

\section{Conclusion}

This study enumerated the revolving issues and trends, divergence and convergence of immigration policies in three other selected liberal democratic states such as the United States of America, Australia and France whose immigration reality offers significant similarities with the UK with a view to situating the analysis of immigration issues in the UK within the broader context of other liberal democracies. By way of convergence and trends, the research has shown that while the UK's 1971 Immigration Act later became the cornerstone of all immigration laws in the UK, about the period between 1971-1999, similar immigration patterns were in operation in the US and France that relieves the argument whether such practices were simply co-incidental, a trend amongst liberal democratic states or mere convergence.

This argument was further cemented by the finding that while the UK used 'not conducive to public good' term as a ground for deportation and automatic deportation of 'foreign criminals', the USA facilitated the deportation of criminal aliens by expanding the definition of aggravated felony to include crimes carrying a prison sentence of one year or more rather than time served. At the time, France used the Pasqua laws to expand the deportation regime through the grant of special powers to immigration officers to detain and deport aliens and Australia applied the 'character test' as a yardstick for deportation. This is with a further finding that the use of discretion rather than law became prominent in the UK and Australia, which queries their coincidence, transplants or diffusion that raise fundamental questions as to whether the form and pattern of immigration control in liberal democratic states is a new legal framework of state power.

The study found that while section 32 of the UK Borders Act 2007 makes provision for automatic deportation of 'foreign criminals' as discussed above, the United States uses the IIRIRA 1996-aggravated felonies- to expand the vistas of deportability of migrants regardless of their length of residence. The Australian section 501 of the Migration Act on the other hand applies the 'character test' to deport migrants regardless of their length of residence. This leads to the contention that the supposedly synergy of deportation practices by these liberal states in the form of convergence could not have been by accident but suggests either a legal transplant or policy transfer.

Ultimately and owing to these immigration realities, the authors are critical of the practicability of the liberal democratic policies and ideals of fairness and human rights protection. Tracing these anomalies from the beginning, offers transparent and unbiased views of the fault line wherein the burgeoning phenomenon of immigration control sits uncomfortably and how this line separates the prerogatives of State sovereignty from the rights of non-citizens regardless of the broad discretion of States to control immigration.

\section{References}

[1] Flynn, M. (2012). Who must be detained? Proportionality as a tool for critiquing immigration detention policy. Refugee Survey Quarterly, 31 (3), 40-68.

[2] Goodwin-Gill, G. S. (1975). The limits of the power of expulsion in public international law. British Yearbook of International Law, 47 (1), 55-156.

[3] Gibney, M. J., \& Randall Hansen, R. (2003). Deportation and the liberal state: the forcible return of asylum seekers and unlawful migrants in Canada, Germany and the United Kingdom. Oxford: United Nations Office of the High Commissioner for Refugees.

[4] Plattner, M. F. (2010). Democracy's Past and Future: Populism, Pluralism, and Liberal Democracy. Journal of Democracy, 21 (1), 81-92.

[5] Smith, R. (2010). Constitutional Democracy, Coercions and Obligations to Include. In the Limits of Constitutional Democracy by Jeffrey Tulis and Stephen Macedo (eds), 37. Princeton University Press) 280.

[6] Ramcharan, B. G. (2011). The fundamentals of international human rights treaty law. Brill.

[7] Groenendijk, C. A., Guild, E., \& Dogan, H. (1998). Security of residence of long-term migrants: A comparative study of law and practice in European countries. Council of Europe.

[8] Cosmas Ukachukwu Ikegwuruka, The Legality of Deportation and the Removal of Migrants in the United Kingdom within the context of Liberal Democracy (Scholars' Press 2018) 95.

[9] Helena Wray, 'The Aliens Act 1905 and the Immigration Dilemma' (2006) 33 Journal of Law and Society 302, 303; for further information about this Act see the following Ann Dummet and Andrew Nicol, Subjects, Citizens, Aliens and Others: Nationality and Immigration Law (Weidenfield and Nicolson 1990) 27; T. W. E Roche, The Key in the Lock: A History of Immigration Control in England from 1066 to the Present Day (1st edn, John Murray Publishers Ltd 1969) introductory pages; Robert Winder, Bloody Foreigners: The Story of Immigration to Britain (Little Brown 2004) 1-15, 192. 
[10] Robert French, 'The Role of the Courts in Migration Law' (Migration Review Tribunal and Refugee Review Tribunal Annual Members' Conference 25 March 2011) 10.

[11] A typically non-white immigration policy as explained in Herbert Ira London, Non-white immigration and the "White Australia" policy (New York University Press, 1970) 11 cited in Robert French, 'The Role of the Courts in Migration Law' ibid, 6 .

[12] The Migration Act 1958 (Cth) s 6, s 12 and s 22.

[13] Federation For American Immigration Reform, 'History of U.S. Immigration Laws: Historical Immigrant Admission Data; $1821-$ 2006 ' $<$ http://www.fairus.org/site/PageNavigator/legislation.ht $\mathrm{ml}>$ accessed 24 February 2019.

[14] The Immigration Nationality Act (INA) 1952 $<$ http://www.uscis.gov/laws/immigration-and-nationality-act > accessed 15 December 2019.

[15] Warren R Leiden and David L Neal, 'Highlights of the U.S. Immigration Act of 1990' (1990) 14 (1) Fordham International Law Journal 328, 329.

[16] See the Illegal Immigration Reform and Immigrant Responsibility Act 1996, s 305, s 307, s 321.

[17] See the Illegal Immigration Reform and Immigrant Responsibility Act 1996 s 321, s 324.

[18] Labour Inspector $<$ http://www.eurofound.europa.eu/emire/FRANCE/LABOURI NSPECTOR-FR.htm> accessed 04 May 2015.

[19] Police

National $<\mathrm{http}$ ://www.interieur.gouv.fr/sections/a_1_interieur/la_police nationale/organisation/dcpaf $>$ accessed $0 \overline{4}$ May 2016.

[20] Virginie Guiraudon, 'Immigration Policy in France' Brookings $<$ http://www.brookings.edu/articles/2002/0101 france_guiraud on.aspx $>$ accessed 06 May 2017.

[21] Immigration Laws in France (by A J) $<$ http://www.ac.aup.fr/ ggilbert/contentpages/Immigration_La ws.html >accessed 27 February 2012.

[22] Eleonore Kofman, Madalina Rogoz and Florence Lévy, 'Family Migration Policies in France' (2010) International Centre for Migration Policy Development 1, 6.

[23] Liza Schuster, 'Turning Refugees into illegal migrants: Afghan Asylum seekers in Europe' (2011) 34 Ethnic and Racial Studies 1392, 1393, in this paper Schuster looked at impediments to the expulsion of Afghanistan nationals from France owing to refusal of the country to readmit them.

[24] Sev Ozdowski, 'The Law, Immigration and Human Rights: Changing the Australian Immigration Control System' (1985) 19 International Migration Review 535, 537 <http://www.jstor.org/stable/2545855 > accessed 24 February 2018.

[25] Migration Act 1958 (Cth) s 7 (1).

[26] Migration Act 1958 (Cth) s 51A-s 64.

[27] Savitri Taylor, 'From Border Control to Migration Management: The Case for a Paradigm Change in the Western Response to Transborder Population Movement' (2005) 39 (6) Social Policy and Administration 563, 570.
[28] Bridget Anderson, "Illegal Immigrant": victim or villain (2008) 64 ESRC Centre on Migration and Policy Working Paper 73, 3.

[29] Steve Peers, 'Free Movement, Immigration Control and Constitutional Conflict' (2009) 5 European Constitutional Law Review 173, 173.

[30] Treaty on European Union, Art 6.

[31] Tim Finch, 'Immigration under Labour' (Prospect Institute for Public Policy Research 2010) 9 www.prospectmagazine.co.uk accessed 07 April 2018.

[32] Nicholas De Genova, "Migrant "Illegality" and Deportability in everyday life' (2002) 31 Annual Review Anthropology 419, 425.

[33] See Immigration Act 1972, Sch 2 on detention and deportation.

[34] Connor Johnson, 'Indefinite Immigration detention: can it be justified?’ (2009) 23 J. I. A. L 351, 352.

[35] Alice Bloch and Liza Schutter, 'At the extremes of exclusion: Deportation, detention and dispersal' (2005) 28 Ethnic and Racial Studies 491, 499.

[36] The 1971 Act, Sch 2, paras, 8, 9, 16 (2) as amended by the 1999 Act, s. 140 (1), cf The.

[37] Immigration Rules para $2 \mathrm{HC} 395$ as a corollary to the Act. [1995] Imm AR 348 (Leggatt LJ).

[38] See the Nationality, Immigration and Asylum Act 2002, s 62

[39] J F Hollifield, V F Hunt and D J Tichenor, 'The Liberal Paradox: Immigrants, Markets and Rights in the United States' (2008) 61 (1) SMU Law Review 67, 72.

[40] This can be found at 8 USC. A 123 (a) (6); (8 USC Chapter 12-Immigration and Nationality) http://www.law.cornell.edu/uscode/text/8/chapter-12 accessed 21 September 2012.

[41] Stephanie Silverman, 'Immigration Detention in America: A History of its Expansion and a Study of its Significance' (2010) Centre on Migration, Policy and Society Working Paper 80, 13.

[42] T Miller, 'The Impact of mass incarceration on immigration policy' in M. Mauer and M. Chesney-Lind (eds) Invisible Punishment: The Collateral Consequences of Mass Imprisonment (New Press 2002) 214-238.

[43] A E Loughran, 'Congress, Categories and the ConstitutionWhether Mandatory Detention of Criminal Aliens Violates Due Process' (2003-2004) 18 (4) Georgetown Immigration Law Journal 681, 696.

[44] Ralph Grillo, "'Saltdean can't cope" protests against asylum seekers in an English seaside surb' (2005) 28 (2) Ethnic and Racial Studies 235, 237.

[45] Daniel Kanstroom, 'Criminalising the undocumented' (2004) 29 North Carolina Journal of Int'l Law and Commercial Regulation 639, 640.

[46] (2004) 208 ALR 124.

[47] Sections 189, 196 and 198 of the Migration Act 1958. 
76 Cosmas Ikegwuruka and Ugonna Chimnonyerem Nkwunonwo: 'As It Was in the Beginning': An Examination of the Convergence, Divergence and Dilemmas of Immigration Practices in Some Selected Liberal Democratic States

[48] Migration Act 1958, s 183.

[49] A v Australia, HRC Case No 560/1993, para 9.4; see also C v Australia, HRC Case No. 900/1999; Report of the Working Group on Arbitrary Detention (24 October, 2002) UN Doc. E/CN. 4/2003/8/Add. 2.

[50] Woolley \&Anor; Ex parte Applicants M276/2003 by their next friend GS (M276/2003) [2004] HCA 29, 7 October 2004.

[51] Mahran Behrooz v MIMIA, Attorney-General of the Commonwealth of Australia, Australasian Correctional Management Pty Ltd and Australasian Correctional Security Pty Ltd, 6 August 2004.

[52] Ophelia Field and Alice Edwards, 'Alternatives to Detention of Asylum Seekers and Refugees' (2006) UNHCR Legal and Protection Policy Research Series Polas/2006/03 $<$ http://www.unhcr.or> accessed 25 September 2019, 102; see also HREOC, 'A last resort?'The National Inquiry into Children in Immigration Detention, Executive Summary, April 2004, para 1.

[53] See Article L-521-2 of the Administrative Justice Code.

[54] Saadi v UK [2008] 47 EHRR 17, para 65.

[55] Helen O'Nions, 'Exposing the flaws in the Detention of Asylum Seekers: A critique of Saadi' (2008) 17 Nottingham Law Journal 34, 42, for general discussions regarding the 'presence' of asylum seekers and refugees, see Rosemary Sales, 'Welfare for asylum seekers in Britain' (2002) 22 Critical Social Policy 456, 459.

[56] Rusu v Austria App No 34082/02 (ECtHR 2 October 2008).

[57] Cathryn Costello, 'Human Rights and the Elusive Universal Subject: Immigration Detention Under International Human Rights Law and EU Law' (2012) 19 Indiana Journal of Global Legal Studies 257, 286.

[58] 538 US 510 (2003).

[59] J K Doucleff, 'Denmore v Kim: Upholding the Unnecessary Department of Legal Permanent Residents, Supreme Court Review' (2003) 94 Journal of Criminal Law and Criminology 625,650 .

[60] K Beyens and S Snacken, 'Prison Privatisation: An International Overview and the Debate'. (Prison 2000 Conference, University of Leicester 8-10 April 2000) 5.

[61] T. Newburn, 'Atlantic Crossings: "Policy transfer" and crime control in the United States and Britain' (2002) 4 (2) Punishment and Society 165, 194.

[62] D. Garland, The Culture of Control: Crime and Social Order in Contemporary Society (OUP 2001).

[63] T. Jones and T. Newburn, 'Comparative Criminal Justice Policy Making in the United States and the United Kingdom: The Case of Private Prisons' (2005) 45 British Journal of Criminology 58, 60 .

[64] Al James and others, Privatising Prisons: Rhetoric and Reality (Sage 1997); A Coyle, A Campbell and R Neufeld (eds) Capitalist Punishment: Prison Privatisation and Human Rights (Zed Books 2003).

[65] S J A Talvi 'It Takes a Nation of Detention Centres to Hold Us Back' Interview with Michael Welch, Associate Professor of Criminal Justice at Rutgers University Lip Magazine (21 January 2003).
[66] Nora V. Demleitner, 'Immigration Threats and Rewards: Effective Law Enforcement Tools in the "War" on Terrorism' (2002) 51 EMORY Law Journal 1059, 1059.

[67] Juliet P. Stumpf, 'Doing Time: Crimmigration Law and the Perils of Haste' (2011) 58 UCLA Law Review 1705, 1710.

[68] See UK Borders Act 2007, s 32 and 33.

[69] Explanatory Notes to the UK Borders Act 2007.

[70] See UK Borders Act 2007 s 33 (2) Exception 1 is where removal of the foreign criminal in pursuance of the deportation order would breach - (a) a person's Convention rights, or (b) the United Kingdom's obligations under the Refugee Convention. (3) Exception 2 is where the Secretary of State thinks that the foreign criminal was under the age of 18 on the date of conviction.

[71] Section 55 of the Borders, Citizenship and Immigration Act 2009 provides for the duty regarding the welfare of children which mirrors Article 3 (1) of UN Convention of the Rights of the Child (adopted 20 November 1989, entered into force 2 September 1990) UNTS 1577 (CRC).

[72] Rocky Gurung v SSHD [2012] EWCA Civ 62; SS (Nigeria) v SSHD [2013] EWCA Civ 550; AJ (Bangladesh) v SSHD [2013] EWCA Civ 493; Richards v SSHD [2013] EWCA Civ 244.

[73] Stephen H. Legomsky, 'The New Path of Immigration Law: Asymmetric Incorporation of Criminal Justice Norms' (2007) 64 Walsh and Lee Law Review 469, 1727.

[74] See the United Kingdom's 1971 Act, the 2009 Act, the 2004 Act and the 2007 Act.

[75] Cf. the U.S.'s sections, 101 and 237 of the Immigration and the Nationality Act 2006 and section 108 of the Illegal Immigration Reform and Responsibility Act 1996.

[76] IIRIRA increased deportations by the expansion of categories of migrants subject to deportation; see J Ryan Moore, 'Reinterpreting the Immigration and Nationality Act's Categorical Bar to Discretionary Relief for "Aggravated Felons" in Light of International Law: Extending Beharry v Reno' (2004) 21 Arizona Journal of International and Comparative Law 535, 537; see also Jacqueline Hagan, Brianna Castro \& Nestor Rodriguez, ' The Effect of U.S. Deportation Policies on Immigrant Families and Communities: Cross-Border Perspectives' (2009-2010) 88 North Carolina Law Review 1799, 1800.

[77] See the Explanatory Note to the UK Borders Act 2007, Part 5.

[78] See Secretary of State for the Home Department, 'Memorandum to the Home Affairs Committee: Postlegislative Scrutiny of the UK Borders Act 2007 (Cm8459 October 2012)

[79] See commentaries by Jacqueline Hagan, Karl Eschbach \& Nestor Rodriguez, 'U.S. Deportation Policy, Family Separation and Circular Migration' (2008) 42 International Migration Review 64, 65; Nancy Morawetz, 'Understanding the Impact of the 1996 Deportation Laws and the Limited Scope of Proposed Reforms' (2000) 113 Harvard Law Review 1936, 1955.

[80] See Immigration Act 1971, s 3 (5) (a) and the UK Borders Act 2007, s 32 (4). 
[81] Elizabeth C Borja, 'Brief Documentary History of the Department of Homeland Security 2001 - 2008' (Homeland Security-History Office) $<\mathrm{http} / / /$ www.aila.org/content/default.aspx?docid=37572>acces sed 13 December 2013.

[82] See Home Office UK Border Agency, 'Our work in your region' <http://www.ukba.homeoffice.gov.uk/aboutus/yourregion/ > accessed 13 December 2013.

[83] Alan Watson, Legal Transplants: An Approach to Comparative Law (2nd edn, University of Georgia Press, 1993) 29 (Legal transplant- a movement of a system of law from one country to the other usually a diffused law); David Dolowitz, Stephen Greenwold and David Marsh, 'Policy Transfer: Something Old, Something New, Something Borrowed, But Why Red, White And Blue?' (1999) 52 (4) Parliamentary Affairs 719, 720 .

[84] Cf. section 33 of the 2007 Act with decisions in Rocky Gurung v SSHD, SS (Nigeria) v SSHD and AJ (Bangladesh) v SSHD.

[85] Nancy Morawetz, 'Understanding the Impact of the 1996 Deportation Laws and the Limited Scope of Proposed Reforms' (2000) 113 Harvard Law Review 1936, 1943.

[86] See comments by Jennifer Chacon, 'A Diversion of Attention? Immigration Courts and the Adjudication of Fourth and Fifth Amendment Rights' (2010) 59 Duke Law Journal 1563, 1571.
[87] Jennifer Lee Koh, 'Waiving Due Process (Goodbye): Stipulated Orders of Removal and the Crisis in Immigration Adjudication' (2012-2013) 91 North Carolina Law Review $475,481$.

[88] Peter L. Markowitz, 'Deportation is Different' (2010-2011) 13 University of Pennsylvania Journal of Constitutional Law 1299, 1302.

[89] Section 12 of the Migration Act 1958 was amended by section 10 of the Migration Amendment Act 1983.

[90] Michelle Foster, 'An "Alien" By the Barest of the Threads"The Legality of the Deportation of Long-Term Residents From Australia' (2009) 33 Melborne University Law Review 483, 507.

[91] Clemence Richard and Nicolas Fischer, 'A legal disgrace? The retention of deported migrants in contemporary France' (2008) 47 Social Science Information 581, 590.

[92] See Code de l'entrée et du sejour des etrangers et du droit d'asile [Code on the Entry and Stay of Foreigners and on the Right of Asylum] (France) art L521-3 [Nawaar Hassan trans] cited in Michelle Foster, "An "Alien" By the Barest of the Threads"-The Legality of the Deportation of Long-Term Residents From Australia' (n1304); see also Cimade, 'Centres et locaux de retention administrative, Rapport 2007 (2008) cited in Clemence Richard and Nicolas Fischer, 'A legal disgrace? The retention of deported migrants in contemporary France' (2008) 47 Social Science Information 581, 598. 